\title{
Cyclohexene Synthesis by Catalytic Cracking of Cyclohexylarenes
}

\author{
Yasuo Yamazaki*, Tadashi Kawai* and Yasuaki IshikURA*
}

\begin{abstract}
The cracking behavior of cyclohexylarenes over various catalysts was investigated to develop an effective method for cyclohexene synthesis. The reaction was carried out in the vapor phase under atmospheric pressure using a conventional fixed bed flow apparatus. Cyclohexylbenzene (CHB) was cracked quantitatively over silica-alumina catalysts, but the main products were methylcyclopentenes and only a small amount of cyclohexene was obtained. By loading molybdena on the silica-alumina catalysts, the selectivity of cyclohexene increased but the conversion of CHB decreased, and significant amounts of methylcyclopentenes and some biphenyl, dehydrogenated product of $\mathrm{CHB}$, were found. On the other hand, 2,4-dimethyl-1-cyclohexylbenzene (2,4-DMCHB) and 2,4,6-trimethyl-1-cyclohexylbenzene (2,4,6-TMCHB) compared with $\mathrm{CHB}$ were more easily cracked over the $\mathrm{MoO}_{3}-\mathrm{SiO}_{2}-\mathrm{Al}_{2} \mathrm{O}_{3}$ catalysts, but methylcyclopentenes still were considerably produced. The selective cracking of 2,4,6-TMCHB to cyclohexene occurred on $\mathrm{NaOH}-\mathrm{Al}_{2} \mathrm{O}_{3}$ catalysts. Conversion and selectivity under the most suitable reaction conditions were $91 \%$ and $95 \%$, respectively. These results suggest that the selective interaction between aryl group and acid sites on the catalyst is important for selective cracking to cyclohexene, and it will occur when the acidity of the catalyst is weak and the basicity of the aryl group is strong. Further, the kinetics of the cracking reaction of 2,4,6TMCHB over $\mathrm{NaOH}-\mathrm{Al}_{2} \mathrm{O}_{3}$ was studied, and some mechanistic schemes of the reaction were proposed.
\end{abstract}

\section{Introduction}

Several attempts have been made recently to produce cyclohexene by partial hydrogenation of benzene. Platinum catalysts supported on polymers such as various nylons ${ }^{1,2)}$ and polyacrylonitrile ${ }^{1}$, ruthenium catalysts supported on $\mathrm{NiO}^{3)}, \mathrm{TiO}_{2}{ }^{3}$ or carriers pretreated with metal salt ${ }^{4)}$, and modified ruthenium catalysts with $\mathrm{Ni}$, Co or $\mathrm{Fe}$ on carriers $^{5}$ ) have been used for the reaction. However, the selectivity and yield of cyclohexene are not sufficient, as these catalysts produce considerable amounts of cyclohexane.

Cyclohexylbenzene can be produced with a selectivity of above $80 \%$ by hydrogenation of benzene on bifunctional catalysts such as $\mathrm{Ni}-\mathrm{SiO}_{2-}^{-}$ $\mathrm{Al}_{2} \mathrm{O}_{3}{ }^{6) \sim 8)}$. Generally, such a reaction has been called hydroalkylation or hydrodimerization. As shown in our previous paper ${ }^{9}$ describing catalyticdehydrogenation of cyclohexylarenes over chromia-alumina catalysts, CHB was readily and selectively dehydrogenated to biphenyl, but some of cyclohexylarenes were cracked to cycloolefins and arenes besides they were dehydrogenated. On the other hand, 2,4,6-TMCHB was cracked almost

Received Aug. 10, 1981.

* Department of Industrial Chemistry, Faculty of Technology, Tokyo Metropolitan University (2-1-1, Fukasawa, Setagaya-ku, Tokyo 158) selectively to 1,3,5-trimethylbenzene and cycloolefins. These results suggest that cyclohexene synthesis may be possible by the following novel routes:

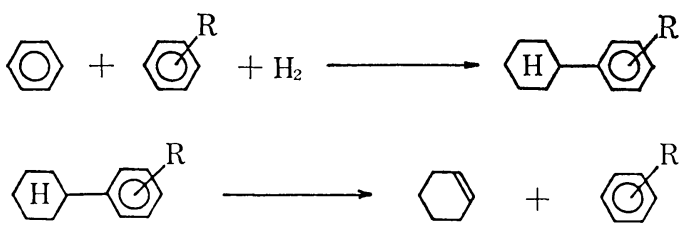

Methylcyclopentenes, besides cyclohexene, were produced in significant amounts in the reaction of cyclohexylarenes over chromia-alumina ${ }^{9}$. Therefore, a more effective catalyst will be required for selective formation of cyclohexene.

In this paper, the cracking behavior or some cyclohexylarenes over various catalysts was studied, however, keeping constantly in mind the selective synthesis of cyclohexene.

\section{Experimental}

\subsection{Catalysts}

Catalysts used were $\gamma$-alumina, silica, silicaalumina, molybdena-alumina, molybdena-silicaalumina, cobalt oxide-molybdena-alumina and $\gamma$-alumina treated with alkali salts. Among these, $\gamma$-alumina, silica and cobalt oxide-molybdena-alumina were commercially available and the others were prepared by conventional methods. The catalysts were used after calcination in a stream of 
air at $650^{\circ} \mathrm{C}$ for $3 \mathrm{hr}$. The particle size was $10-$ 20 mesh.

\subsection{Gyclohexylarenes}

Cyclohexylbenzene, 2,4-DMCHB and 2,4,6TMCHB were chosen as substrates. These substrates were prepared by alkylation ${ }^{10)}$ of benzene, $m$-xylene, and mesitylene with cyclohexanol respectively, in the presence of concentrated sulfuric acid, and they were purified by rectification. Their purities determined by GLG were found to be above $99 \%$.

\subsection{Apparatus and Procedure}

Experimental runs were carried out in a conventional flow apparatus similar to that described in a previous paper'). Prior to each run the catalyst packed in the reactor was pretreated in situ in a stream of nitrogen or hydrogen at $500^{\circ} \mathrm{C}$ for $2 \mathrm{hr}$, then cooled to the reaction temperature. The substrate and dry nitrogen as a diluent were fed to the reactor at a controlled rate. The product at steady state was collected for analysis in a cold trap at regular intervals. The material balance was approximately $95 \mathrm{wt} \%$.

The standard reaction conditions were as follows: reaction temperature, $400^{\circ} \mathrm{G}$; contact time $(\mathrm{W} / \mathrm{F}), 10.5 \mathrm{~g}$-cat $\cdot \mathrm{hr} / \mathrm{mol} ; \mathrm{N}_{2} /$ substrate mole ratio, 5.13 ; pressure, $1 \mathrm{~atm}$; and catalyst, $2.0 \mathrm{~g}$.

\subsection{Analysis}

Reaction products were analyzed mainly by gas chromatography (PEG $20 \mathrm{M}$ column $5 \mathrm{~m}$, 50$220^{\circ} \mathrm{C}$ programming). Effluents from the column were identified by a comparison of retention times with those of the authentic samples. A GC-Mass spectrometer was also used for identification in some cases.

\section{Results and Discussion}

\subsection{Preliminary Search of Catalysts}

A preliminary search to select an effective catalyst for the cracking reaction was carried out using
2,4-DMCHB as a substrate. The results are summarized in Table 1. 2,4-DMCHB was quantitatively cracked over silica-alumina, which is a typical catalyst for cracking hydrocarbons, but the main products of olefins were methylcyclopentenes, and only a slight amount of cyclohexene was found in the product. Moreover, cyclohexene was found to be readily isomerized to methylcyclopentenes over silica-alumina because of its strong acidic properties as will be described later. Thus, silicaalumina was not suitable for cyclohexene synthesis.

In the reaction of 2,4-DMCHB over molybdenaalumina pretreated in a stream of nitrogen, cyclohexene was formed in considerable quantities, but dehydrogenated products such as 2,4-dimethylbiphenyl and dimethylphenylcyclohexenes were also formed. And over both molybdena-silica-alumina and cobalt oxide-molybdena-alumina pretreated in a stream of nitrogen, cyclohexene was formed in appreciable quantities while dehydrogenated products were formed only in small quantities. The pretreatment of these catalysts in a stream of hydrogen resulted in a decrease in cyclohexene and an increase in dehydrogenated products.

\subsection{Reactions of Cyclohexylarenes over Mo- lybdena-silica-alumina}

Preliminary search indicated that the molybdenasilica-alumina catalyst pretreated with nitrogen was relatively effective for cyclohexene synthesis. Therefore, some detailed studies on the catalyst were further attempted.

\subsubsection{Reaction of Gyclohexylbenzene}

The effect of molybdena content in the catalysts affecting the reaction of CHB is shown in Fig. 1. Over the silica-alumina as a carrier, $\mathrm{CHB}$ was cracked with a conversion of $86 \%$ to benzene and methylcyclopentenes, which composed mainly of 1 -methyl isomer. The conversion decreased strikingly by loading a small amount of molybdena

Table 1 Activities and Catalytic Behavior of Various Catalystsa)

\begin{tabular}{|c|c|c|c|c|}
\hline $\begin{array}{l}\text { Catalyst } \\
(\mathrm{wt} \%)\end{array}$ & $\begin{array}{l}\text { Treatment } \\
\text { Gas }\end{array}$ & $\begin{array}{c}\text { Conversion } \\
(\%)\end{array}$ & $\begin{array}{c}\text { Cyclohexene } / m \text {-Xylene } \\
\text { (mole ratio) }\end{array}$ & $\begin{array}{c}\text { Selectivity of } \\
\text { 2, 4-Dimethylbiphenyl }(\%)\end{array}$ \\
\hline 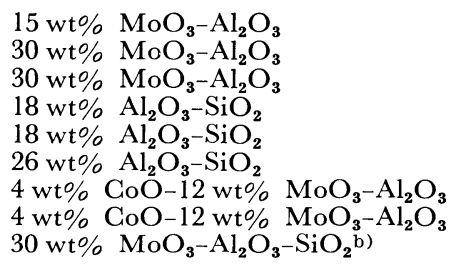 & $\begin{array}{l}\mathrm{N}_{2} \\
\mathrm{~N}_{2} \\
\mathrm{H}_{2} \\
\mathrm{~N}_{2} \\
\mathrm{H}_{2} \\
\mathrm{~N}_{2} \\
\mathrm{~N}_{2} \\
\mathrm{H}_{2} \\
\mathrm{~N}_{2}\end{array}$ & $\begin{array}{r}40 \\
40 \\
60 \\
100 \\
100 \\
100 \\
60 \\
10 \\
30\end{array}$ & $\begin{array}{l}0.50 \\
0.80 \\
0.25 \\
\text { tr. } \\
\text { tr. } \\
0.10 \\
0.80 \\
0.50 \\
0.85\end{array}$ & $\begin{array}{l}10 \\
10 \\
7 \\
\text { tr. } \\
\text { tr. } \\
\text { tr. } \\
1 \\
39 \\
\text { tr. }\end{array}$ \\
\hline
\end{tabular}

a) Reaction temperature $: 400^{\circ} \mathrm{C}$, Contact time (W/F) : $10.4 \mathrm{~g}$-cat $\cdot \mathrm{hr} / \mathrm{mol}, \mathrm{N}_{2} / 2,4-\mathrm{DMCHB}$ mole ratio $: 5.13$

b) $28 \mathrm{wt} \% \quad \mathrm{Al}_{2} \mathrm{O}_{3}-\mathrm{SiO}_{2}$ 


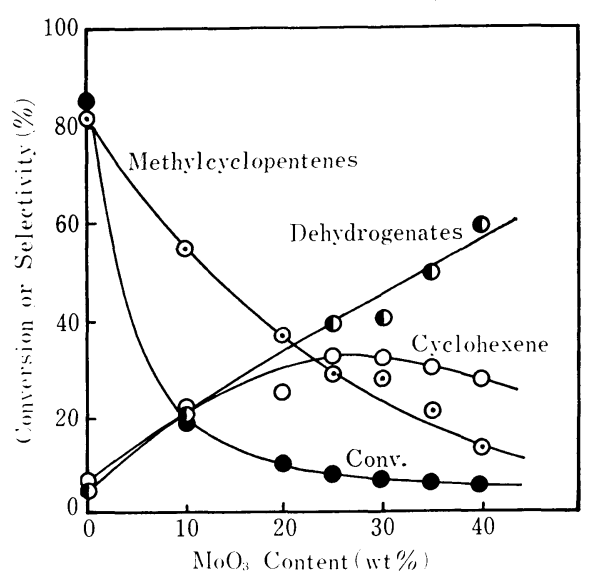

Carrier : $26 \mathrm{wt} \% \mathrm{Al}_{2} \mathrm{O}_{3}-\mathrm{SiO}_{2}$, Reaction temperature : 400 ${ }^{\circ} \mathrm{C}$, Contact time (W/F) : $10.5 \mathrm{~g}$-cat $\cdot \mathrm{hr} / \mathrm{mol}, \mathrm{N}_{2} / \mathrm{CHB}$ mole ratio : 5.13

Fig. 1 Effect of Molybdena Content on Conversion and Cracking Behavior

on the silica-alumina. With increase in the molybdena content, selectivity of methylcyclopentenes decreased and that of dehydrogenates increased. The selectivity of cyclohexene was maximum when the molybdena content was about 30 $\mathrm{wt}^{\%} \%$. But the selectivity was still not sufficient, in spite of the low conversion level, and comparable amounts of dehydrogenates and methylcyclopentenes were formed.

The effect of composition of silica-alumina as a carrier is shown in Fig. 2. $30 \mathrm{wt} \%$ molybdena was loaded on each carrier. The conversion of CHB was generally very low but it increased slightly with increase in the alumina content up to ca. $26 \mathrm{wt} \%$ and then it decreased with higher levels of alumina content. When the content was

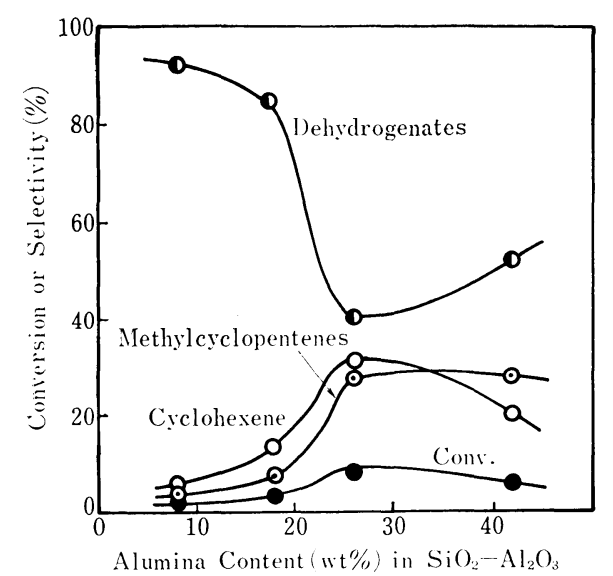

$\mathrm{MoO}_{3}$ content : $30 \mathrm{wt} \%$, Reaction temperature : $400^{\circ} \mathrm{C}$, Contact time (W/F) : $10.5 \mathrm{~g}$-cat $\cdot \mathrm{hr} / \mathrm{mol}, \mathrm{N}_{2} / \mathrm{CHB}$ mole ratio : 5.13

Fig. 2 Effect of Composition in Silica-Alumina on Conversion and Cracking Behavior less than $18 \mathrm{wt} \%$, dehydrogenates were formed predominantly. The selectivity of dehydrogenates decreased remarkably with increasing alumina content, becoming a minimum at $26 \mathrm{wt} \%$. On the other hand, cyclohexene and methylcyclopentenes attained their maxima at $26 \mathrm{wt} \%$ alumina content, but they were formed in almost equimolar amounts. Thus, $30 \mathrm{wt} \%$ molybdena catalyst supported on $26 \mathrm{wt} \% \quad \mathrm{Al}_{2} \mathrm{O}_{3}-\mathrm{SiO}_{2}$ showed its maximum activity for cracking and minimum for dehydrogenation.

The formation of cyclohexene and methylcyclopentenes in the reaction of CHB over silica-alumina and molybdena-silica-alumina will be explained by the following scheme based on the interaction between acidic sites on the catalyst and phenyl ring in $\mathrm{CHB}$.

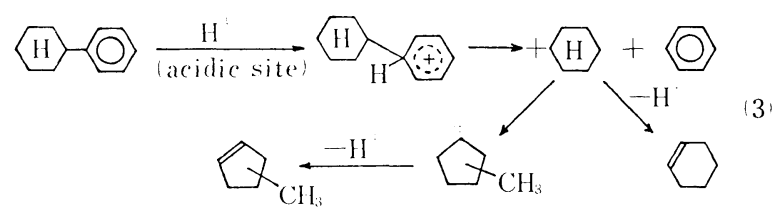

On the other hand, the interaction between molybdena and $\mathrm{CHB}$ will bring about the formation of dehydrogenates such as biphenyl and phenylcyclohexene, since the selectivity of dehydrogenates increases with increase in the molybdena content of the catalyst. The formation of dehydrogenates will be explained by the following scheme referring to the study reported by Thorsteinson et al.11).

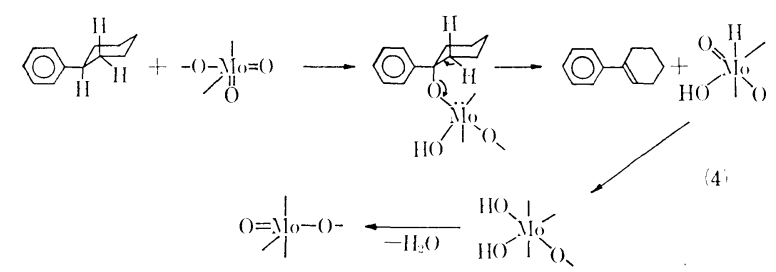

That is, the cyclohexyl ring in CHB reacts with the coordinately unsaturated $\mathrm{Mo}(\mathrm{VI})$ species to form a hydroxylated species as an intermediate and then phenylcyclohexene and $\mathrm{Mo}(\mathrm{IV})$ species are produced. The $\mathrm{Mo}(\mathrm{IV})$ species containing an oxo, hydroxy, and hydride ligand group attached to the same $\mathrm{Mo}(\mathrm{IV})$ atom is unstable and rearranges readily to a $\mathrm{Mo}(\mathrm{IV})$ dihydroxy species.

The changes in catalytic activity and product distribution as shown in Fig. 1 by varying the molybdena content may be interpreted reasonably by Eqs. (3) and (4). That is, with the increase in the amount of molybdena supported on silicaalumina, the surface of the carrier is covered with molybdena, and this decreases the number of strong acid sites that have the ability to crack 
substrate and to isomerize cyclohexyl carbonium ion to methylcyclopentyl carbonium ion as shown by Eq. (3). Consequently, the conversion of CHB and the selectivity of methylcyclopentenes decrease, and cyclohexene increases to some extent. To the contrary, the selectivity of dehydrogenates increases with increasing degree of interaction between molybdena species and cyclohexyl ring in CHB. The results shown in Fig. 2 also seem to suggest that acid properties of a catalyst influence the cracking behavior.

In this connection, the behavior of cyclohexene over molybdena-silica-alumina catalyst was examined, and the results obtained are shown in Fig. 3. Gyclohexene was converted almost quantitatively over the silica-alumina as a carrier and isomerized with approximately $80 \%$ selectivity to methylcyclopentenes. With the increase in the amount of molybdena supported on the silicaalumina, the conversion of cyclohexene and selectivity of methylcyclopentenes decreased but the amount of benzene as a dehydrogenate increased slightly in contrast to that of CHB.

The molar ratio of methylcyclopentenes to cyclo-

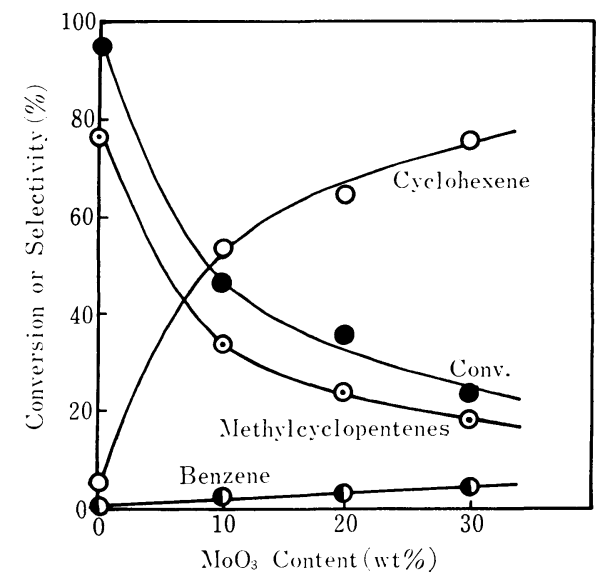

Carrier : $26 \mathrm{wt} \% \mathrm{Al}_{2} \mathrm{O}_{3}-\mathrm{SiO}_{2}$, Reaction temperature : 400 ${ }^{\circ} \mathrm{C}$, Contact time $(\mathrm{W} / \mathrm{F}): 10.5 \mathrm{~g}-\mathrm{cat} \cdot \mathrm{hr} / \mathrm{mol}, \mathrm{N}_{2} /$ Cyclohexene mole ratio : 5.13

Fig. 3 Reaction of Cyclohexene over $\mathrm{MoO}_{3}-\mathrm{SiO}_{2}-\mathrm{Al}_{2} \mathrm{O}_{3}$ Catalysts hexene should be the same for cyclohexylarenes if these olefins were produced only by Eq. (3). However, the ratio differed widely according to the substrate used as shown in Table 2 although the same catalyst and reaction conditions were employed. This suggests that some other production routes to methylcyclopentenes are possible. One of the possible routes is the isomerization of cyclohexylarene to methylcyclopentylarene and its subsequent cracking, that is;

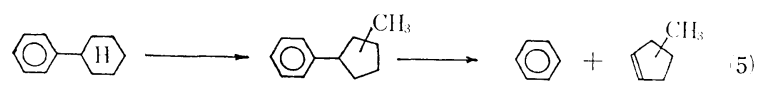

Isomerization in Eq. (5) will take place through the interaction between molybdena and the cyclohexyl group in cyclohexylarene as shown in Eq. (6).

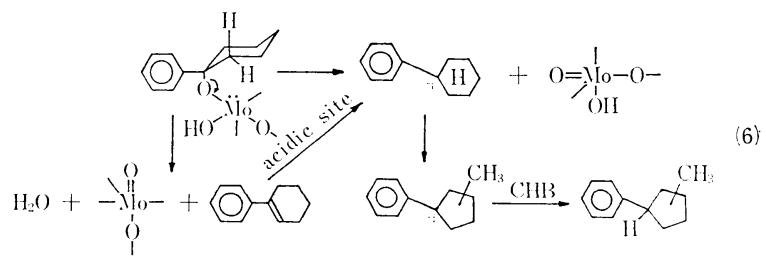

The reason for the difference in the ratio will be further discussed in 3.2.2 and 3.3.

\subsubsection{Reaction of Gyclohexylarenes}

Cyclohexylbenzene was not a suitable substrate for selective synthesis of cyclohexene as described in 3.2.1. One of the reasons might be that the poor interaction between acid sites on catalyst and the phenyl group in CHB. If so, the selective interaction between acid sites and aryl group would increase with increase in the basicity of the aryl group, and this will lead to a selective reaction and also to a higher activity.

The effect of basicity of the aryl group in cyclohexylarenes on the cracking behavior was examined over a fixed catalyst. Both reactions of 2,4DMCHB and 2,4,6-TMCHB over $30 \mathrm{wt} \%$ molybdena on $26 \mathrm{wt} \% \quad \mathrm{Al}_{2} \mathrm{O}_{3}-\mathrm{SiO}_{2}$ were carried out, and the results obtained are summarized in Table 2. Each substrate was cracked mainly to cyclo-

Table 2 Cracking Behavior of Cyclohexylarenes over a Fixed Catalysta)

\begin{tabular}{c|c|rr}
\hline \multirow{2}{*}{ Substrate } & \multirow{2}{*}{ Conversion $(\%)$} & & Selectivity $(\%)$ \\
\cline { 2 - 4 } & & Cyclohexene & Methylcyclopentenes \\
\hline CHB & 6.8 & 31.7 & 29.2 \\
2, 4-DMCHB & 58.8 & 63.3 & 26.5 \\
\hline
\end{tabular}

a) Catalyst : $30 \mathrm{wt} \% \mathrm{MoO}_{3}-\mathrm{SiO}_{2}-\mathrm{Al}_{2} \mathrm{O}_{3}$, Reaction temperature : $400^{\circ} \mathrm{C}$; Contact time (W/F) : 10.5 g-cat.hr/mol, $\mathrm{N}_{2}$ /Substrate mole ratio : 5.13
b) Biphenyl, benzene and others
c ) 3,5-DMCHB
d) Benzene 
olefins with a higher conversion compared with $\mathrm{CHB}$ and only small amounts of dehydrogenates were observed. Although 3,5-DMCHB was found in the reaction product of 2,4-DMCHB, it was thought that 3,5-DMCHB might be formed by the migration of the cyclohexyl group rather than the methyl group. It was also found by further examination that 3,5-DMCHB was more stable for the cracking reaction than 2,4-DMCHB. 2,4,6TMCHB was cracked nearly quantitatively but relatively large amounts of methylcyclopentenes and a small amount of benzene were produced as byproducts. The selectivity of cyclohexene and methylcyclopentenes from 2,4,6-TMGHB corresponded approximately to that obtained from the reaction of cyclohexene as is readily seen by comparing the results given in Table 2 and Fig. 3. This clearly indicates that methylcyclopentenes are produced predominantly by isomerization of cyclohexene.

Among the compounds examined, 2,4,6-TMCHB was the most suitable substrate for cyclohexene synthesis. However, it will be necessary to find a more effective catalyst having little or no isomerization activity for cyclohexene.

\subsection{Reaction of 2,4,6-TMCHB over $\gamma$-Alumina Treated with Alkali Salts}

It was considered that isomerization reaction of cyclohexene to methylcyclopentenes might be caused by strong acid sites. If so, the selection of a catalyst having weaker acidity will be more effective. The reaction of 2,4,6-TMCHB over a commercially available $\gamma$-alumina, its alkali treated alumina, and silica were tried. The results are shown in Table 3 .

On the $\gamma-\mathrm{Al}_{2} \mathrm{O}_{3}$ catalyst, 2,4,6-TMCHB was readily cracked and cyclohexene was obtained with a selectivity of $58 \%$, and $30 \%$ on $\gamma-\mathrm{Al}_{2} \mathrm{O}_{3}$ treated with nitric acid. This difference might be caused by the difference in the number of strong acid sites. Some attempts were made to poison the strong acid sites on $\gamma-\mathrm{Al}_{2} \mathrm{O}_{3}$ treated with nitric

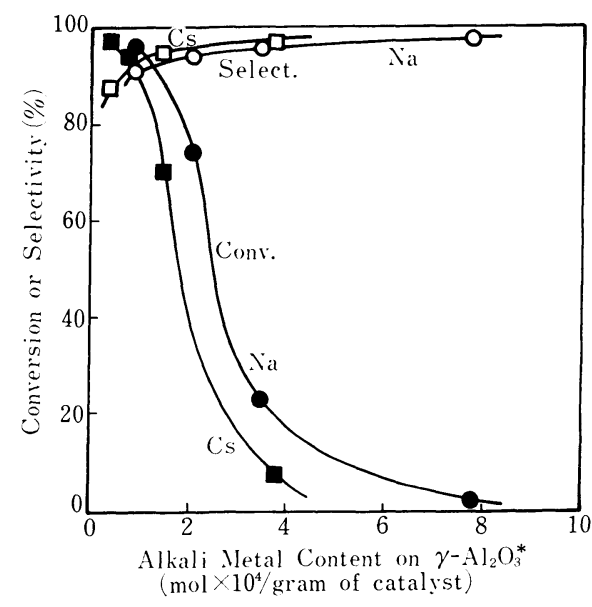

Reaction temperature : $400^{\circ} \mathrm{C}$, Contact time $(\mathrm{W} / \mathrm{F})$ : $10.5 \mathrm{~g}$-cat $\cdot \mathrm{hr} / \mathrm{mol}, \mathrm{N}_{2} / 2,4,6$-TMCHB mole ratio : 5.13

* pretreated with $0.1 \mathrm{~N} \mathrm{HNO}_{3}$

Fig. 4 Effect of Alkali Metal Content on $\gamma-\mathrm{Al}_{2} \mathrm{O}_{3}$

acid by loading it with $\mathrm{NaOH}$ or $\mathrm{CsNO}_{3}$. The selectivity of cyclohexene was improved surprisingly by loading a small amount of an alkali salt as shown in Fig. 4. The reactivity of the substrate decreased only a bit within the loading range of $0.2-0.5 \mathrm{wt} \%$, based on the alkali metal content, and then decreased rapidly with further loading. This strongly indicates that the addition of a small amount of an alkali salt resulted in selective poisoning of the strong acid sites. The decrease in activity by the loading of $\mathrm{CsNO}_{3}$ was greater than that of $\mathrm{NaOH}$ at the same loading level, although the selectivity was almost the same for both catalysts.

Reaction conditions for the selective synthesis of cyclohexene were further investigated using 0.87 wt $\% \mathrm{NaOH}-\mathrm{Al}_{2} \mathrm{O}_{3}$ catalyst. As shown in Figs. 5 and 6, 2,4,6-TMCHB was almost quantitatively and selectively cracked to cyclohexene at any temperature above $400^{\circ} \mathrm{C}$ and at any contact time above $10 \mathrm{~g}$-cat $\cdot \mathrm{hr} / \mathrm{mol}$. The suitable reaction conditions using the $0.87 \mathrm{wt} \% \mathrm{NaOH}-\mathrm{Al}_{2} \mathrm{O}_{3}$ catalyst were: temperature, $400^{\circ} \mathrm{C}$; contact time, 10 g-cat.

Table 3 Cracking Behavior of 2,4,6-TMCHB over Various Catalystsa)

\begin{tabular}{|c|c|c|c|c|}
\hline \multirow{2}{*}{ Catalyst } & \multirow{2}{*}{$\begin{array}{c}\text { Conversion } \\
(\%)\end{array}$} & \multicolumn{2}{|c|}{ Selectivity $(\%)$} & \multirow{2}{*}{$\begin{array}{c}\mathrm{Na} \text { Content } \\
(\mathrm{ppm})\end{array}$} \\
\hline & & Cyclohexene & Methylcyclopentenes & \\
\hline $\begin{array}{l}\left.30 \mathrm{wt} \% \quad \mathrm{MoO}_{3}-\mathrm{SiO}_{2}-\mathrm{Al}_{2} \mathrm{O}_{3} \mathrm{~b}\right) \\
\gamma-\mathrm{Al}_{2} \mathrm{O}_{3} \\
\left.\gamma-\mathrm{Al}_{2} \mathrm{O}_{3} \mathrm{c}\right) \\
\mathrm{SiO}_{2} \\
\left.0.87 \mathrm{wt} \% \mathrm{NaOH}-\mathrm{Al}_{2} \mathrm{O}_{3} \mathrm{c}\right)\end{array}$ & $\begin{array}{l}97.7 \\
98.8 \\
99.5 \\
72.7 \\
90.9\end{array}$ & $\begin{array}{l}72.1 \\
58.5 \\
29.7 \\
92.9 \\
94.9\end{array}$ & $\begin{array}{r}25.5 \\
41.5 \\
70.3 \\
7.1 \\
5.1\end{array}$ & $\begin{array}{r}116 \\
30 \\
5,609\end{array}$ \\
\hline
\end{tabular}

a) Reaction temperature $: 400^{\circ} \mathrm{C}$, Contact time (W/F) : $10.5 \mathrm{~g}$-cat $\cdot \mathrm{hr} / \mathrm{mol}, \mathrm{N}_{2} / 2,4,6-\mathrm{TMCHB}$ mole ratio $: 5.13$

b) $26 \mathrm{wt} \% \mathrm{Al}_{2} \mathrm{O}_{3}-\mathrm{SiO}_{2} \quad$ c) Treated with $0.1 \mathrm{~N} \mathrm{HNO}_{3}$ 


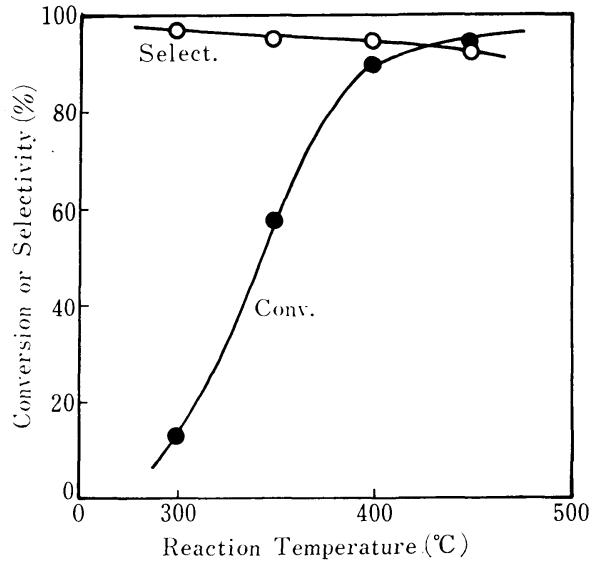

Catalyst : $0.87 \mathrm{wt} \% \mathrm{NaOH}-\mathrm{Al}_{2} \mathrm{O}_{3}$, Contact time $(\mathrm{W} / \mathrm{F})$ : 10.5 g-cat $\cdot \mathrm{hr} / \mathrm{mol}, \mathrm{N}_{2} / 2,4,6$-TMCHB mole ratio: 5.13

Fig. 5 Effect of Reaction Temperature on Conversion and Cyclohexene Selectivity

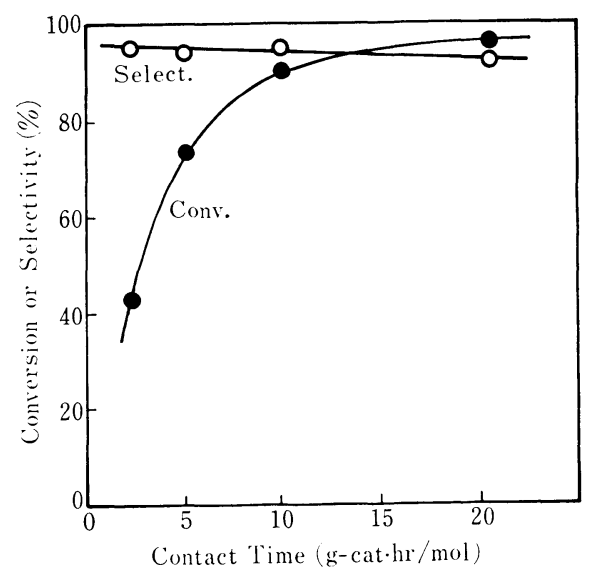

Catalyst : 0.87 wt $\% \mathrm{NaOH}-\mathrm{Al}_{2} \mathrm{O}_{3}$, Reaction temperature : $400^{\circ} \mathrm{C}, \mathrm{N}_{2} / 2,4,6$-TMCHB mole ratio : 5.13

Fig. 6 Effect of Contact Time on Conversion and Cyclohexene Selectivity

$\mathrm{hr} / \mathrm{mol}$. Under these conditions, the conversion of 2,4,6-TMCHB and selectivity of cyclohexene were $91 \%$ and $95 \%$, respectively, and changes in catalytic activity and selectivity were not observed in the $12 \mathrm{hr}$ run.

Reactions of CHB and 2,4-DMCHB over the same catalyst were attempted in connection with the above observations. However, CHB was almost inert and only $7.3 \%$ of 2,4-DMCHB was converted to cyclohexene even under the most favorable reaction conditions for 2,4,6-TMCHB.

\subsection{Kinetics of Catalytic Cracking}

Kinetic studies on the reaction of 2,4,6-TMCHB over the $0.87 \mathrm{wt} \% \mathrm{NaOH}-\mathrm{Al}_{2} \mathrm{O}_{3}$ in which alumina was pretreated with an aqueous nitric acid were carried out under the following conditions: temperature, $310-340^{\circ} \mathrm{C}$; partial pressure of $2,4,6$ -
Table 4 Kinetic Data on Catalytic Cracking of $2,4,6-\mathrm{TMCHB}^{\mathrm{a}}$ )

\begin{tabular}{c|ccc}
\hline $\begin{array}{c}\text { Temperature } \\
\left({ }^{\circ} \mathrm{C}\right)\end{array}$ & $\begin{array}{c}\text { Partial Pressure } \\
P_{\text {TMCHB }}(\mathrm{atm})\end{array}$ & $\begin{array}{c}\text { Conversion } \\
(\%)\end{array}$ & $\begin{array}{c}\text { Initial Rate } \\
r_{\mathrm{o}} \times 10^{3}\end{array}$ \\
\hline 310 & 0.052 & 6.3 & 1.26 \\
& 0.104 & 4.2 & 1.68 \\
& 0.156 & 3.3 & 1.98 \\
& 0.208 & 2.3 & 1.84 \\
\hline 320 & 0.052 & 8.4 & 1.68 \\
& 0.104 & 5.5 & 2.20 \\
& 0.156 & 4.6 & 2.76 \\
& 0.208 & 3.3 & 2.64 \\
\hline 330 & 0.052 & 11.8 & 2.36 \\
& 0.104 & 8.0 & 3.20 \\
& 0.156 & 6.4 & 3.84 \\
& 0.208 & 4.6 & 3.68 \\
\hline 340 & 0.104 & 11.5 & 4.60 \\
& 0.156 & 8.7 & 5.22 \\
& 0.208 & 6.3 & 5.04 \\
\hline
\end{tabular}

a ) Contact time $(\mathrm{W} / \mathrm{F}): 2.6 \mathrm{~g}-\mathrm{cat} \cdot \mathrm{hr} / \mathrm{mol}$

TMCHB $\left(P_{\text {тмCHB }}\right), 0.052-0.208 \mathrm{~atm}$; and contact time $(\mathrm{W} / \mathrm{F}), 2.6 \mathrm{~g}$-cat $\cdot \mathrm{hr} / \mathrm{mol}$. The reaction rate under the above reaction conditions was not affected by the mass transfer of internal and external diffusion of the reactant.

The kinetic data obtained are summarized in Table 4. Assuming that the possible rate-determining steps of the catalytic cracking would be the surface reaction on the catalyst, several reaction mechanisms and their rate equations were formulated and compared with the experimental results. From the kinetic data shown in Table 4, a linear relationship was found between $\left(P_{\text {тмснв }} / r_{0}\right)^{1 / 2}$ and $P_{\text {тмснв }}$. The following elementary reaction schemes are proposed to reflect the above relationship:

$$
\begin{aligned}
& \mathrm{TMCHB}+\sigma \rightleftarrows(\mathrm{TMCHB}) \sigma \quad K_{7} \quad(7) \\
& \text { (TMCHB) } \sigma+\sigma \stackrel{k_{8}}{\longrightarrow}(\mathrm{TMB}) \sigma+(\mathrm{CHen}) \sigma \\
& (\mathrm{TMB}) \sigma \rightleftarrows \mathrm{TMB}+\sigma \\
& 1 / K_{9}(9) \\
& \text { (CHen) } \sigma \rightleftarrows \mathrm{CHen}+\sigma
\end{aligned}
$$

Where $\sigma$ is the vacant site on the catalyst; TMB and $\mathrm{CHen}$ are 1,3,5-trimethylbenzene and cyclohexene, respectively. Using the steady state method, the following rate equation is derived from the above scheme:

$$
r=\frac{k_{8} K_{7} P_{\mathrm{TMCHB}}}{\left(1+K_{7} P_{\mathrm{TMCHB}}+K_{9} P_{\mathrm{TMB}}+K_{10} P_{\mathrm{CHen}}\right)^{2}}
$$

When the partial pressures of the reaction products are negligibly small, Eq. (11) is simplifies as follows:

$$
r_{0}=\frac{k_{8} K_{7} P_{\mathrm{TMCHB}}}{\left(1+K_{7} P_{\mathrm{TMCHB}}\right)^{2}}
$$

Equation (12) can be arranged as a linear function of $P_{\mathrm{TмCHB}}$, such as 


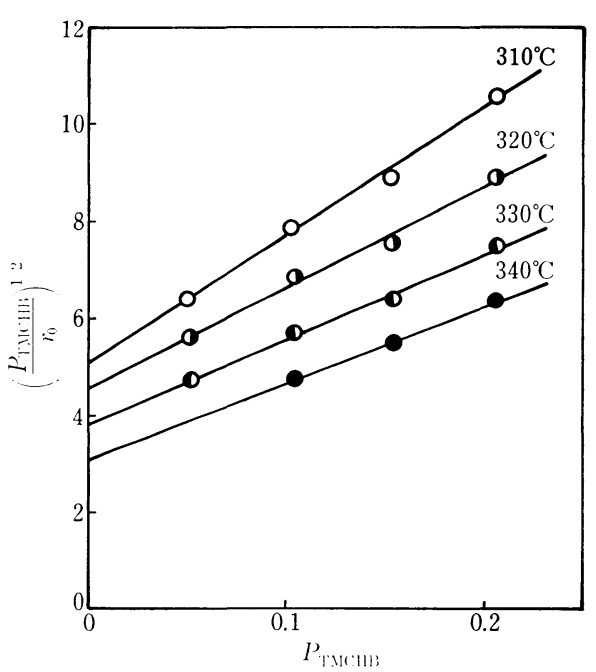

Fig. 7 Verification of Equation (13)

$$
\left(\frac{P_{\mathrm{TMCHB}}}{r_{0}}\right)^{1 / 2}=\left(\frac{1}{k_{8} K_{7}}\right)^{1 / 2}+\left(\frac{K_{7}}{k_{8}}\right)^{1 / 2} P_{\mathrm{TMCHB}}
$$

Experimental data satisfied Eq. (13) as shown in

Fig. 7. The activation energy was calculated to be $12 \mathrm{kcal} / \mathrm{mol}$ from the Arrhenius plots.

The following scheme could be another conceivable scheme:

$$
\begin{gathered}
\mathrm{TMCHB}+\sigma_{1} \rightleftarrows(\mathrm{TMCHB}) \sigma_{1} \\
(\mathrm{TMCHB}) \sigma_{1}+\sigma_{2} \longrightarrow(\mathrm{TMB}) \sigma_{1}+(\mathrm{CHen}) \sigma_{2}
\end{gathered}
$$

$$
\begin{aligned}
& (\mathrm{TMB}) \sigma_{1} \rightleftarrows \mathrm{TMB}+\sigma_{1} \\
& (\mathrm{CHen}) \sigma_{2} \rightleftarrows \mathrm{CHen}+\sigma_{2}
\end{aligned}
$$

That is, if (CHen) $\sigma_{2}$ is negligibly small compared with $\sigma_{2}$, the rate equation derived from the above scheme becomes similar to Eq. (12).

\section{Conclusions}

The following views were clarified from the study of the cracking reaction of cyclohexylarenes over various catalysts in the vapor phase:

(1) Catalysts having strong acid sites, such as silica-alumina, have a high cracking activity but they cause undesirable isomerization of cyclohexene produced by cracking to methylcyclopentenes in large quantities.

(2) The loading of molybdena on silica-alumina by impregnation results mainly in covering the strong acid sites on the carrier. The cracking and isomerization activities decrease and the formation of dehydrogenated products increases with increasing content of molybdena.

(3) The strong acid sites on $\gamma$-alumina having isomerization activity are selectively poisoned by loading a small amount of an alkali salt. The most suitable catalysts observed are $0.87 \mathrm{wt} \%$ $\mathrm{NaOH}-\mathrm{Al}_{2} \mathrm{O}_{3}$ and $0.73 \mathrm{wt} \% \mathrm{CsNO}_{3}-\mathrm{Al}_{2} \mathrm{O}_{3}$.

(4) The most favorable reaction conditions using the $0.87 \mathrm{wt}^{\%} \quad \mathrm{NaOH}-\mathrm{Al}_{2} \mathrm{O}_{3}$ catalyst and 2,4,6TMCHB as a substrate are: temperature, $400^{\circ} \mathrm{C}$; contact time $(\mathrm{W} / \mathrm{F}), 10 \mathrm{~g}$-cat $\cdot \mathrm{hr} / \mathrm{mol}$. The conversion of 2,4,6-TMCHB and the selectivity of cyclohexene under these conditions are $91 \%$ and $95 \%$, respectively.

(5) Among the substrates investigated, 2,4,6TMCHB is the most suitable substrate for the selective synthesis of cyclohexene.

(6) The selective interaction between acid sites and the aryl group in cyclohexylarenes is important for the selective synthesis of cyclohexene, and it becomes possible when the acidity of the catalyst is weak and the basicity of aryl group is strong.

(7) The kinetic study indicates that the ratedetermining step is the surface reaction between adsorbed substrate and vacant sites, and the activation energy is $12 \mathrm{kcal} / \mathrm{mol}$.

\section{References}

1) Dini, P., Dones, D., Montelatici, S., Giordano, N., J. Catalysis, 30, 1 (1973).

2) Harrison, D. P., Rase, H. F., Ind. Eng. Chem. Fund. 6, (2), $161(1967)$

3) Japan. Kokai 73 36, 150.

4) Japan. Kokai 76 98, 243.

5) Johnson, M. M., J. Catalysis, 38, 518 (1975).

6) Slaugh, L. H., Leonard, J. A., J. Catalysis, 13, 385 (1969).

7) Louvar, J. J., Francoy, A., J. Catalysis, 16, 62 (1970) .

8) Yamazaki, Y., Masuda, A., Kawai, T., Kimura, S., J. Japan Petrol. Inst., 18, (1), 25 (1976).

9) Yamazaki, Y., Kawai, T., Yagishita, A., J. Japan Petrol. Inst., 21, 229 (1978).

10) Zargorodii, S. V., et al., Ukr. Khim. Zh., 35, 374 (1969).

11) Thorsteinson, E. M., Wilson, T. P., Young, F. G., Kasai, P. H., J. Catalysis, 52, 116 (1978). 


\title{
シクロヘキシルアレン類の接触分解によるシクロヘキセンの合成
}

\author{
山崎 康男*, 河合 是*, 石倉 泰明*
}

近年，シクロヘキセンの合成方法として，Pt，Pd 系触媒を 用いたベンゼンの部分水素化反応が研究1) 5) されているが，転 化率は低くまたシクロへキサンの副生も多く満足な結果が得ら れていない。さらに，反応生成物中には未反応ベンゼンも含ま れるので，これら成分を単離することは沸点が互いに近似して いるため非常に困難である。著者らはこれまでに $\mathrm{Ni}-\mathrm{SiO}_{2}-$ $\mathrm{Al}_{2} \mathrm{O}_{3}$ 触媒を用いたハイドロアルキレーション（水素化二量化 反応之も呼ばれている) によるシクロへキシルベンゼン(CHB) およびシクロへキシルアレン類の合成8) (Eq. (1)) およびこれ ら化合物の $\mathrm{Cr}_{2} \mathrm{O}_{3} / \mathrm{Al}_{2} \mathrm{O}_{3}$ 触媒による脱水素反応 $\left.{ }^{9}\right)$ にいて検 討してきた。シクロヘキシルアレンはその構造により脱水素反 忘が選択的に起こるものと分解反応が主として起こるもの，ま た両反応が併発して起こるものに大別され，分解生成物として 主にメチルシクロペンテンが得られることを見い出した。

本報はシクロへキセンを選択的に合成する新しい方法として シクロヘキシルアレン類の接触分解反応について検討したもの である (Eq. (2))。反応は固定床気相流通系反応装置を用い 常王下で行った。各種触媒について検討したところ,シリカーア ルミナは分解活性が非常に大きい反面，主反応生成物はメチル シクロペンテンでありンクロへキセンの生成はごくわずかであ った（Fig. 1)。シリカーアルミナにモリブデナを担持した場 合，担持量の增大とともに分解活性，異性化活性は低下しシク ロへキセンの選択率は向上したがモリブデナ担持量約 $30 \mathrm{wt} \%$ で最大となった。一方，脱水素生成物はモリブデナ担持量の増 大とともに増大し $25 \mathrm{wt} \%$ 以上担持した場合には主生成物と なった（Fig. 1)。シクロへキセンのこれら触媒による挙動を 調べたところ Fig. 3 に示したようにシリカーアルミナ上では 約 $80 \%$ が異性化されメチルンクロペンテンになること，およ びモりブデナ担持量の増加とともに異性化活性は低下すること がわかった。また，モリブデナ担持量を $30 \mathrm{wt} \%$ に固定しシ

* 東京都立大学工学部工業化学科（158 東京都世田谷区深沢 2-1-1)
リカーアルミナ組成の反応に及ぼす影響をリアクタントとして CHB を用いて調べたところ Fig. 2 に示したようにアルミナ 含有量が增大するにつれて転化率は若干向上し， $26 \mathrm{wt} \%$ 以上 では低下した。シクロへキセン，メチルシクロペンテンの選択 率の変化も転化率と同様の傾向を示し，シリカーアルミナの酸 性度分布と対応していることが示唆された。一方，脱水素生成 物はアルミナ含有量にかかわらず主生成物であったが $26 \mathrm{wt} \%$ で最低となった。

これらの実験結果から，触媒の強酸点が分解之異性化の主た る活性種であることおよびモリブデナの含浸法による担持によ りシリカーアルミナ上の強酸点がモリブデナで覆われるためいに 分解，異性化活性が低下する反面，モリブデナによる脱水素反 応が促進されることがわかった。リアクタントについてみると Table 2 に示したようにアリール基の塩基性が強い程，分解 されやすくかつシクロへキセンの選択率が向上することがわか った。これらのことから，シクロへキセンを選択的に合成する ためには触媒としては異性化活性の少ない弱酸性の触媒が有利 であり,リアクタントとしてはアリール基の塩基性の強いもの を用いることが好ましいことが示唆された。

2, 4, 6-トリメチル-1-シクロへキシルベンゼン $(2,4,6$-TM$\mathrm{CHB})$ をアアクントとし, シリカ, $\gamma$ アアルミナ, $\gamma$-アルミナ にアルカリ金属塩を担持した触媒についてさらに検討した之

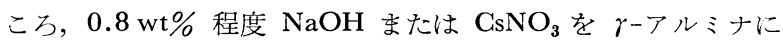
担持した触媒が好ましいことがわかった（Fig. 4)。0.87 wt\% $\mathrm{NaOH}-\mathrm{Al}_{2} \mathrm{O}_{3}$ 触媒を用い， 2, 4, 6- TMCHB をリアクタント とした場 合の最適反応条件は，反応温度 $400^{\circ} \mathrm{C}$ ，接触時間 (W/F) $10 \mathrm{~g}$-cat.hr/mol であり，この条件下に拉ける転化率 およびシクロへキセンの選択率はそれぞれ $91 \% ， 95 \%$ であっ た。

動力学データは, 律速段階が吸着リアクタントと活性点との 表面分解過程であるとした場合に最もよい適合を示した。また 活性化エネルギーは $12 \mathrm{kcal} / \mathrm{mol}$ であることがわかった。

\section{Keywords}

Alumina catalyst, Cyclohexene, Cyclohexylarene, Catalytic cracking, Isomerization, Methylcyclopentene 